\title{
9 A Reparative Approach to Parole-Release Decisions
}

\author{
Kristen Bell
}

When Richard Martin ${ }^{1}$ was a teenager, he ran away from an abusive home. A 46-year-old man took him in, and repeatedly drugged and raped him. When Richard was 16 , his abuser told him to kill a man and steal a truck. He did so. Three weeks later, Richard brought himself to a police station and confessed. He was convicted of murder and sentenced to life in prison with the possibility of parole. A sentence of life with the possibility of parole ("term-to-life" sentence) means that Richard had to serve a set number of years in prison, after which he became eligible for a hearing in which a parole board could grant or deny release on parole. Unlike most states, California recognizes a legal presumption in favor of granting release on parole which can be defeated by some evidence that a person poses a current danger. The parole board decided to approve Richard for release on three separate occasions, and each time the decision was reversed.

In 2013, California passed Senate Bill 260, a statute requiring that parole hearings be a "meaningful opportunity for release" for people who committed crimes at a young age. The law essentially put a thumb on the scale in favor of release at youthful offender parole hearings. Over 250 people have been released from prison under this law to date, and it was expected that Richard would be among them (Kuznia 2016). Despite the fact that Richard has a clean record in prison and has engaged in almost all the rehabilitation programs that the prison has to offer, the parole board again denied his release. A commissioner on the parole board felt that Richard was not enthusiastically participating in the process of answering their questions.

As of this writing, Richard is 55 years old and remains incarcerated in a California State Prison. He struggles with depression; as he has told the parole board, he has lost faith in the process.

Richard's story is not unique, a number of similar stories are chronicled in "False Hope," a report by the American Civil Liberties Union that details the broken nature of the parole-release process across the nation (Mehta 2016). In California, one-third of the entire prison population is serving a term-to-life sentence ("lifers"), meaning they will die in prison unless the parole board approves their release (Nellis 2013). Across the nation, over 110,000 people are serving term-to-life sentences (Nellis 2013: 6). "The 
number of people serving life sentences has more than quadrupled since 1984-a faster rate of growth than the overall prison population." (Ghandnoosh 2017: 3). Procedural protections at parole hearings are minimal and variable (Ruhland et al. 2016: 23), as is the rate at which parole boards approve prisoners for release (Mehta 2016; Schwartzapfel 2015). In California, for example, the parole board granted parole in approximately $27 \%$ of all the lifer parole hearings that it conducted in 2015, but almost no one was released under the reign of Governor Gray Davis in 1999-2003 (Board of Parole Hearings 2015; Kobrin 2005; Weisberg 2011: 15). In Florida, the parole grant rate is less than one percent, and in Ohio the grant rate ranges between four percent and nine percent (Mehta 2016: 46). In stark contrast, the Arkansas parole board granted parole in 71 percent of the cases it reviewed in 2015 (Mehta 2016).

Many state parole boards also have release authority over hundreds of thousands of prisoners who are serving sentences that are shorter than term-to-life (Ruhland et al. 2016: 14). In non-term-to-life cases that go before the parole board, people are generally serving sentences within a range fixed by a judge (for example, 7-10 years), and the parole board decides on a release date at some point within that range. The rate at which parole boards release people before the maximum date of their term is generally higher than the rate of release in term-to-life cases. For example, the Georgia parole board approved release for 11 percent of people serving term-to-life sentences, but its general grant rate (including non-life sentences) was 56 percent (Mehta 2016: 47). Of note, however, research from one state shows that the parole grant rate among non-life sentences is disparate across racial lines: a study of the general parole grant rate in New York State in 2013-2016 showed a release rate of 25\% for white prisoners and $15 \%$ for African American prisoners (Winerip 2016). An older study of the New York parole system found that the variability and unpredictability of parole-release decisions increased as the severity of the crime increased (Vera Institute of Justice 1978).

The arbitrary and politicized nature of parole-release systems is an easy target to criticize, but proposals for effective reform are few and far between. Some consider reform hopeless and have advocated for abolishing parole-release systems in favor of sentences with pre-determined end dates and specific good-time reduction credits (American Bar Association 1994). The federal government and several states abolished or otherwise contracted parole-release systems in the 1970s through the 1990s (Rhine 2012: 631-632), but many of these jurisdictions have seen increases in the amount of time that people serve in prison and little (if any) improvement in the fairness of sentencing (Nellis 2013). In Louisiana, for example, people serving term-to-life sentences in prison used to be regularly released on parole after having served a decade in prison, but after the abolition of parole-release, 4,657 people are now serving life without the possibility of parole sentences (11\% of Louisiana's prison population). Of those 4,657 people, $73.4 \%$ are 


\section{Kristen Bell}

African American (Nellis 2013). In recent years, states that had previously contracted parole-release systems are once again expanding them (Ruhland et al. 2016: 15).

In 2016 and 2017, advocates and scholars have proposed several recommendations for meaningful reform of the parole-release process (Mehta 2016; Rhine 2017; Ghandnoosh 2017). A primary objective of the recommendations is to curtail discretion in parole-release decisions; as one expert has said, parole-release decisions have long been the most visible display of discretion in the criminal justice system (Rhine 2012). To reduce arbitrary decision making, the recommendations propose depoliticizing parole boards, reducing the amount of time served before the first parole hearing, increasing procedural protections at hearings, and establishing a strong presumption in favor of release.

Left largely unexplored, however, is the normative project of analyzing what substantive criteria ought to guide parole-release decisions. I undertake this normative project here, reviewing how four different moral theories of punishment would structure parole-release criteria. I consider two general objections to each of these approaches, and then turn to draw lessons from how one state's parole-release system functions in practice. Learning from both the theoretical and practical perspectives on the question of parole-release criteria, I suggest that a fundamentally different approach to parole-release criteria is required. I propose a "reparative approach" that builds on aspects of restorative justice and takes seriously respect for the moral agency of prisoners, victims, and the broader political community.

\section{Four Theoretical Approaches to Parole-Release Decision Criteria}

In this section, I describe the approach to parole-release decision criteria from the perspective of four received theories of punishment: a retributive theory, deterrence theory, rehabilitation theory, and communicative theory. I do not sketch multifaceted policy proposals, but seek only to identify the basic decision-release criteria that are grounded in the core commitments of these theories of punishment.

Although the four theories of punishment I consider purport to provide a moral justification of punishment, it is an open question whether any of them actually justify the contemporary practice of term-to-life sentences or other prison sentences with the option of parole-release. I do not address the moral justifiability of such sentences here, but assume for the purpose of the paper that they are a relatively fixed point in the American landscape for the foreseeable future. The project here is to identify what guidance (if any) these theories of punishment can provide in the design of parole-release decision criteria. I aim to be ecumenical regarding theories of punishment in this paper; that is, I do not herein object to any of the theories themselves. 
I argue in the next section, however, that each of the parole-release decision criteria are objectionable on two basic grounds.

In focusing on how different theories of punishment would inform parole-release decision criteria, I am suggesting that the central question in making a parole-release decision is when and whether punishment should end. The central question, however, may be considerably more complex, depending on how one conceives of punishment and the function of parole. ${ }^{2}$ Arguably, punishment does not end when a person is released on parole. When a person is granted release on parole, she is placed under state supervision and instructed to abide by a specific set of parole terms. If she is found to be in violation of those terms, she is returned to prison on her original sentence. The central inquiry of the parole-release decision thus may not be whether punishment should cease, but rather whether punishment should occur in the community rather than in the prison. Research on this question is critical, but I save it for future work. For the purpose of this paper, I assume that a full normative account of parole will need to address the question of when and whether punishment should end, and I consider that question from the perspective of four received views of punishment.

Retribution. The core commitment of a retributive theory is that punishment is morally justified on the basis of the principle that people who commit crimes deserve to suffer in proportion to the gravity of the crime. Given that the amount of punishment is keyed to the gravity of the crime-which is known at the time of conviction-retributivists have reason to favor determination of sentence lengths at the time of conviction. For various reasons, retributivists tend to favor sentences that cover a general range of time (for example, 7-10 years) rather than a specific time period. Within the range of time, a retributivist may favor basing parole-release decisions on a variety of factors that are morally relevant, but not grounded in retributivism; for example, by an assessment of dangerousness, by employment skills, or by the needs of dependent family members who need the prisoner to take care of them.

If pressed to identify release criteria that are grounded in the core commitments of retributive theory, a theorist would have (at least) two options. First, a retributivist could base release decisions on whether a person has actually experienced an amount of suffering that is proportional to the gravity of the crime. The amount of actual suffering that individuals experience from the same length of incarceration varies considerably due to differences in conditions of confinement as well as people's individual characteristics. A person who has actually experienced more suffering compared to others convicted of a similarly grave crime would have grounds for release earlier within the sentencing range.

A second parole-release criterion based in retributive theory concerns transformational change in the person who committed the crime. Some retributivists maintain that the fittingness of a punishment to a given crime 


\section{Kristen Bell}

loses its grip if the person who committed the crime undergoes a deep change in character. The person who committed the crime deserves punishment because she stands behind the crime, or is committed to the moral view that the crime expressed. If a person changes over time and continually separates herself from the crime as a reprehensible action which she deeply regrets, she no longer stands behind the crime and it may no longer makes sense for her to be punished for it (Hampton 1988: 154). A person who demonstrates this change would have grounds for release earlier within the sentencing range.

Communicative. The core insights of a communicative theory of punishment are that (i) political communities ought to communicate condemnation of crime in order to express the wrongness of criminal actions, (ii) punishment communicates such condemnation, and (iii) insofar as criminal punishment is morally justified, its justification relies to some degree on the aim of punishment to express condemnation. ${ }^{3}$ A communicative theory, like a retributive theory, may rely on criteria for parole-release decisions that are exogenous to the communicative aim. If pressed to develop criteria within the theory, a natural criterion for a communicative theorist would be whether a perpetrator has understood and recognized the community's message about the wrongness of her past criminal conduct. This would include understanding both that the violation is wrong and why it is wrong, and embracing a commitment to abide by the law in the future not (only) as a prudential matter, but as a matter of what is owed to the community (Duff 2011: 373).

Parole boards might seek to answer the central inquiry by prompting a person to explain how the crime happened, why she did it, and inviting her to express her current perspective on the action. The parole board might also look to whether the person has done her best to understand the attitudes or values that led them to her crime, and to explain what she has done to change those attitudes. In grave crimes, the parole board may consider whether a person has taken action to make amends (for example, paying restitution, fundraising for charities, repairing relationships, etc.) as a way of showing that she fully understands the depth of her wrongdoing.

Deterrence. The core claim of a general deterrence-based theory of punishment is that punishment is justified when (and if) punishing people for crime is an effective method of reducing or preventing crime in the community. Deterrence theorists take punishment to be justified only up to the point where resources used on punishment return greater crime-reduction outcomes compared to alternatives. A deterrence theorist would base release decisions on a utility function that is sensitive to factors including crime rates, economic incentives for committing crimes, public perception of the harshness of punishment, cost of incarceration, and predictions of how a person will behave upon release. A person would be released from prison when the utility function indicates that the cost of incarcerating a person would have smaller public safety benefits than releasing the person. 
Some deterrence theorists are less interested in "general deterrence" (which purports to justify punishing a person in order to deter others from crime), and instead focus on "special deterrence" or "incapacitation" (which purports to justify punishing a person in order to prevent that person from committing crime in the community). On a theory of special deterrence, the parole board would not consider the full utility function, but limit itself to consideration of the probability that a person would commit a future crime if released. A person would be released if the probability falls below a given benchmark. The theory itself does not settle what the benchmark should be.

Of note, some have proposed grounding parole-release decisions in a mixed view of retribution and special deterrence (Rhine et al. 2016: 14-17). Sentences would be structured such that there is a range of time that "fits" the crime, and release decisions within that range would be made on the basis of judgments about whether the individual is likely to commit another crime if released.

Rehabilitation. A rehabilitation theory of punishment holds that punishment is justified only when (and if) punishing people for crime is an effective method of improving people's ability to function as pro-social members of the community. Punishment in prison is thought to help people improve themselves, but after a certain point, improvement is better achieved outside of prison walls. On this view, a parole board ought to release an individual at "just the right time" to help a person succeed in re-entering society. A person should not be released too early (i.e., when she would still benefit more from time in prison), nor too late (i.e., when she would be stagnated by spending more time in prison). To determine "just the right time" for release, parole boards look to whether people have taken full advantage of rehabilitation programs available in the prison, to their re-entry options, and to the opinions of prison staff and psychologists. Of note, the rehabilitation framework was taken to be the theoretical underpinning of operative parole-release systems in the 1960s and 1970s, although it was unclear whether actual practice reflected this ideal (Rhine 2012).

\section{Two General Objections}

Each of the criteria described above is subject to (at least) two general types of objection. The first type of objection concerns the limits on our ability to assess fairly or measure the various proposed criteria. The second concerns failure to respect the moral agency of people in prison.

Limits on fair assessment. Given the nature of the criteria proposed by each of the four theories, we have limited ability to know whether or not the criteria are fulfilled in any given case. The limitations on our knowledge are somewhat different for each theory. With respect to both the retributive and communicative theories, we are limited because we are not equipped to peer into a person's psyche and discern whether she has undergone personal transformation and/or understood the depth of her wrongdoing. Outward 


\section{Kristen Bell}

indicators like expressions of remorse, apology, and efforts toward amends can provide some evidence of transformation and/or understanding, but we have no mirror into a person's authentic conscience (Hampton 1988).

With respect to the deterrence and rehabilitation theories, we are limited because we lack a "crystal ball" that can predict a person's future behavior upon release from prison. Actuarial risk assessment tools and expert opinions of psychologists may provide estimated probabilities of whether a person will commit a crime or improve herself if released from prison, but such estimates are not proof of future conduct. Early empirical studies of parole hearing decisions and recidivism underscore the point (Scott 1974; Garber and Maslach 1977; Carroll 1978; Holland 1978; Carroll et al. 1982). Consider one study that compiled case summaries of 200 former parolees, half of whom violated parole and half of whom successfully completed parole and were discharged. Two groups of people-(i) experienced parole officers and (ii) accountants-were asked to read the case summaries and decide who would fail on parole and who would succeed. The parole officers did slightly worse than the accountants, and neither group made better predictions than would have resulted from chance alone (Garber and Maslach 1977: 264). Research in actuarial risk assessment tools have progressed since the time of that study, and parole boards are relying increasingly on these tools. (Ruhland et al. 2016). There is reason to believe that the accuracy of parole boards in making predictions about future conduct has improved and will continue to improve. Nevertheless it is unlikely that accuracy will rise to the level of proof beyond a reasonable doubt.

The problem with the inherent uncertainty in the criteria proposed by the four theories is not simply a lack of accuracy, but the fact that the uncertainty invites decision makers to exercise idiosyncratic discretion that in turn engenders arbitrary decision making. Worse, given the nature of some of the criteria, the exercise of discretion will tend to disadvantage some prisoners relative to others on the basis of morally irrelevant factors. With respect to the retributive and communicative criteria, people will fare better at convincing decision makers of transformation and understanding if they are intelligent, understand the culture of the decision makers, and are skilled at comporting themselves and articulating themselves within that culture. People from linguistic and cultural minorities, people who have difficulties in expressing themselves, and people with deficits in understanding or in communicating complex ideas will tend to fare worse. With respect to deterrence and rehabilitation criteria that look to predictions of future conduct, people of color and people from poor, disadvantaged communities will tend to fare worse. Actuarial risk assessment tools tend to overestimate the level of risk they pose because they have fewer past indicators of stability (Larson et al. 2016).

Robust procedural protections might mitigate some of the unfairness here. But we should think twice about designing a system which relies on criteria that invite arbitrary decisions and unfairness from the outset. 
Failure to Respect Moral Agency. Even if we could reliably and fairly measure each of the proposed criteria, there are deontic moral reasons to object to each of them. In different ways, each of the criteria fail to respect people in prison as moral agents-that is, as agents with the capacity to accept moral norms and values through their own judgment, and with the capacity to conform their actions to those norms and values.

Consider first the deterrence view which involves conditioning release from prison on a prediction about whether a person will commit a crime in the future. Keeping a person in prison because a state official has deemed it necessary to prevent her from responding to some imagined future stimuli treats her as an animal, not an autonomous agent equipped with the capacity to understand moral reasons and make choices. To be clear, the problem is not that acting on predictions about a person's future conduct necessarily fails to respect that person's agency. The problem is that the state is determining the harshness of criminal punishment-the amount of time a person spends locked up in a place overtly designed to set back the interests of culpable individuals - on the basis of a prediction about a person's response to some imagined future stimuli. This treats a person as a dangerous, caged animal; not a person who is a co-member of the political community.

In a different way, the other three proposed criteria also fail to respect the moral agency of people in prison. Personal transformation, understanding, and rehabilitation all include a person accepting norms and values for pro-social conduct in society. When the state conditions release from prison on acceptance of prevailing norms and values, it is not respecting a person's status as an agent with the capacity to accept those norms on the basis of her own judgment. Instead, the state is using the threat of prolonged incarceration to coerce a person into accepting those norms and values by force. Such use of force raises moral concern in two ways: first, it is generally wrong to use force on a moral agent unless or until she changes her mental state. Doing so fails to respect her moral agency; in the words of Martin Luther King, this type of action is "immoral because it seeks to humiliate the opponent rather than win his understanding." Second, it is generally wrong for the state to so coerce a person because of limits on legitimate state authority. We recognize that such state coercion over the content of mental states is wrong as applied to free people, and the same principle ought to apply to people in prison (Tadros 2011: 355).

Given this concern, and the importance of respect for agency that both the retributive and communicative embrace, pure retributive and communicative theorists may ultimately oppose the proposed criteria I sketched above. Most notably, a leading defender of communicative theory, Antony Duff, has made it clear that punishment "must seek to persuade (but not to coerce or manipulate) [a person convicted of a crime] to repent his crime and to accept his punishment as a penance for that crime, while leaving him free to remain unpersuaded and unrepentant" (Duff 2001: 177, emphasis added.) Conditioning release from prison on adopting an attitude of understanding 


\section{Kristen Bell}

would violate this principle. It may be that communicative and retributive theorists would ultimately favor the reparative approach that I describe at the end of this chapter, but the issue merits further thought into the weeds of these theories that is beyond the scope of this paper.

\section{The Practice of Making Parole Decisions}

Having considered parole-release criteria from the perspective of four different theories of punishment, I now consider how one jurisdiction has implemented some of these criteria in the context of term-to-life sentences. I consider California because it has the third largest prison population in the country after the federal government and the state of Texas (Carson 2015: 3), and the largest population of people serving term-to-life sentences (Ghandnoosh 2017). As of 2012, approximately one in three people in California prisons was serving a term-to-life sentence, meaning that they will die in prison unless the parole board finds them suitable for release on parole (Nellis 2013: 6). Parole is far from a guarantee for these prisoners; from 2000 to 2011, more prisoners serving life sentences for murder died in prison than were released on parole (Mullane 2012: 147). Although California has some of the most robust procedural protections at parole hearings compared to other states (Mehta 2016), its parole-release grant rate nevertheless varies remarkably from one political regime to the next (Ghandnoosh 2017: 16). Social scientists and legal commentators have written a great deal about California's parole process (for example, Weisberg 2011; Young 2016; Caldwell 2016); my discussion here is limited to a brief summary of the legal framework and a critical evaluation of the underlying normative framework.

California law requires the parole board to grant parole unless it finds that a person poses an unreasonable risk to public safety. The law's sole focus on risk to public safety makes it appear that the California parole system is designed to operate under the "special deterrence" framework described above. After a person has served the minimum amount of time proportionate to her offense, she is to be released unless the parole board predicts that she will commit another crime or violate a term of parole if released (In re Reed [2009] 171 Cal.App.4th 1071, 1081). If the board denies parole, it must exhaustively list its reasons for doing so and explain why there is evidence of current dangerousness. That evidence cannot rely solely on facts about the crime or a person's history prior to the crime (In re Lawrence [2008] 44 Cal.4th 1181). The facts of the crime and other past history can be included as evidence of current dangerousness, however, if there is a "rational nexus" between the crime and the person's recent conduct or mental state (In re Shaputis [2011] 53 Cal.4th 192, 218).

With this cursory description of the framework in place, I turn to describe three morally problematic features of the California parole process. First, as discussed above, grounding decisions on predictions about future conduct 
fails to respect people as moral agents and invites a great deal of arbitrariness into decisions. Of two people with similar case factors, one may be deemed dangerous and denied, whereas the other is deemed not dangerous and granted. Although the parole board states its reasons for every decision, the factors are so murky that the real reason behind a given denial are often left a mystery. What one prisoner said about the mysteriousness of the parole process in another state is equally true in some cases in California: "I feel like I am chasing a ghost" (Mehta 2016).

Second, California's focus on special deterrence at parole hearings is inconsistent with its concern for proportionate sentencing. California law recognizes a proportionality principle in that prisoners are required to serve a minimum number of years that is proportional to the crime before becoming eligible for a parole hearing. But because current law does not recognize a ceiling on the maximum punishment (other than natural death), the system produces outcomes that are perverse from the perspective of proportionality. Consider two 18-year-old co-defendants who had equal culpability in committing a crime, and who were both given a sentence of 7-years-to-life. Suppose one co-defendant was a smart, articulate prisoner who followed rules and was released on parole at age 25 after having served 7 years in prison. Suppose the second co-defendant is continually denied parole because she is frequently written up for non-serious violations of prison rules which the parole board believes to be correlated with a risk of recidivism. Suppose the second co-defendant dies in prison at age 68 after having served 50 years. She has served a sentence that is not only more than 7 times longer-but an entire lifetime longer-for the very same crime. Given that the state has adopted a retributive principle as the reason to set a floor on the minimum punishment, it is inconsistent with that principle to permit such an extraordinarily wide range of punishment without a ceiling.

Third, in practice, there is a gulf between the criterion that the law requires the parole board to use-whether or not a person will re-offend if released (special deterrence)—and the criteria that the parole board actually considers in exercising its discretion. As the following discussion shows, the board is strongly influenced by concerns apart from deterrence that are rooted in the retributive, rehabilitation, and communicative aspects of punishment. My discussion here is informed by several studies of California parole hearings as well as reading transcripts from California parole hearings for people serving life sentences for juvenile convictions (Weisberg 2011; Young 2016; Caldwell 2016).

California lifer parole hearings are laden with expressions of condemnation for the crime, and with questions about whether a person recognizes the depth of her wrongdoing. Questions about the crime and past criminal history often consume much of the hearing; in some cases, questions about a decades-old crime have lasted over three hours. Hearings close with a statement by the district attorney and the victim or victim's next of kin (if they choose to make a statement) which are generally prolonged expressions 


\section{Kristen Bell}

of condemnation. In addition, the parole board seeks to determine whether the prisoner has "gone deep" in taking personal responsibility understanding her role in crime. If a person attributes the commission of her crime to "external factors" such as drug use and peer pressure within a street gang, the board is likely to think she is "minimizing" her own criminal mindset at the time. The board told one man that they wanted to hear him say he was "a monster" for having sold crack on a street corner at age 16 (transcript on file with author). The board regularly cites the heinousness of the crime, inadequacy of remorse, and insufficient change in attitude since the time of the crime as reasons to deny parole. The discourse is far closer to what you would expect to hear from a retributivist or a communicative theorist (or a hard-nosed priest and a penitent in a confessional) than it is to a collection of data points on predicting future conduct.

The parole board also spends roughly $10-20 \%$ of a lifer parole hearing asking questions about rehabilitative programs that a prisoner has participated in. When the parole board decides to deny parole, it often cites lack of participation in rehabilitation programs as among the reasons for denial-even if the person did not have access to those programs in prison (Caldwell 2016: 289). In one case, the parole board denied a man who served decades in prison for a juvenile conviction who scored "low risk" on a psychological risk assessment and had a near perfect disciplinary record in prison (transcript on file with author). The board remarked that the man had not participated in any programs in prison, and did not appreciate his attitude that he wanted to simply'serve out the time that he owed for his crime. More generally, the parole board looks fondly upon a prisoner if she has written book reports (Caldwell 2016: 289). Logistic regression analysis of over 700 California lifer parole hearings has shown that failure to answer a question about the 12 Steps of Alcoholics/Narcotics Anonymous (a substance abuse program offered in California prisons) significantly impacts the likelihood of being granted parole (Young 2016: 275). It is unclear whether writing book reports or being able to recite the 12 Steps reduces the chance of committing crime upon release. But it is clear that these pieces of evidence show engagement with rehabilitation and with what the parole board thinks is "good for inmates" to do in prison.

Finally, the purported focus on special deterrence does not square with the fact that parole is granted in murder cases at a far lower rate than other crimes. In California, people convicted of murder have the lowest recidivism rates compared to any other crime; according to the California Department of Corrections and Rehabilitation's most recent outcome report, only $2.6 \%$ of people convicted of murder who were released returned to prison, whereas $44.6 \%$ of all people released returned to prison (California Department of Corrections 2016). The same trend holds true across the nation (Mehta 2016: 67). If the parole board's concern were solely on preventing future crimes, one would expect people convicted of murder to have relatively high rates of release on parole. But the opposite is true. Nationally, 
parole rates for people convicted of less serious offenses (especially nonviolent offenses) are far higher than for those convicted of murder (Mehta 2016: 46-7).

For these reasons, the California parole board does not in practice appear to satisfy its purported goal of making release decisions solely on the basis of predictions about future crime. One lesson advocates could draw from this practice is that more strict procedures are needed in order for the parole board to live up to its purported goal. For example, strict rules of evidence could be implemented to specify what counts as relevant, reliable evidence for measuring the risk of dangerousness. The rules could preclude consideration of factors (like a decades-old crime) whose relevance tends to be outweighed by prejudicial value. The state could train decision makers to focus only on the specified types of reliable evidence for recidivism, and could engage the courts in robust judicial review of the decisions to enforce those rules.

Although such procedures are necessary and would improve the parole system, it is unclear whether they would actually succeed in getting parole board members to make decisions solely on the basis of current dangerousness. Practice suggests that retributive, communicative, and rehabilitation concerns sincerely matter to people as they make these decisions. It may be psychologically unrealistic to expect people to weed out values that matter to them in the context of such high-stakes decisions. A better way forward may be to design parole-release decision making in a way that recognizes a variety of considerations in a structured fashion, rather than asking decision makers to contort their vision into seeing through a single lens.

Moreover, even if improved procedures could make parole decisions turn solely on the criterion of dangerousness, the system would remain unjust in light of the two objections articulated above: the looseness of "dangerousness" invites arbitrary decision making, and continued incarceration based on predictions of future conduct fails to respect the moral agency of people in prison. Furthermore, an additional injustice also arises given that the system is operating upon non-ideal social conditions. Many, if not most, people serving life sentences in California have endured deep injustice and trauma in their lives that affected their commission of the crime. In a sample of 107 people serving life sentences for juvenile convictions, 62\% experienced sexual, physical, or emotional abuse prior to the crime (Caldwell 2016: 276). In addition to having experienced direct abuse, people discuss having been homeless, having witnessed their mothers or siblings being raped or beaten, having been shot at or having seen friends shot at, having developed an addiction to drugs and alcohol at a very young age (for example, under 10 years old), having been brought into a street gang as a teen by older family members, and not having received any help in school for learning disabilities or trauma.

As Duff and others have argued, such circumstances of disadvantage and exclusion from the community ought to have a mitigating effect on 


\section{Kristen Bell}

punishment. Among other things, such circumstances undercut the state's moral standing to make the perpetrator of crime answer for that crime (Duff 2001: 186-200). In the context of a parole system ostensibly grounded in special deterrence, however, these circumstances are used as reasons in favor of denying parole. Like many actuarial risk assessment tools, the California parole board explicitly deems an "unstable social history" to be predictive of dangerousness (California Code of Regulations., Title 15, $\mathbb{S} 2402$ ). The very features that deprived a person of an equal chance in life before the crime are used to disadvantage them further in parole decisions. Further, the state stands in a position of hypocrisy when it demands that prisoners accept full personal responsibility for the crime and express understanding of their role in the crime, while the state itself never acknowledges or addresses the role that it played in engendering conditions of injustice that underlay the crime.

\section{The Reparative Approach}

Having identified some of the challenges in designing parole-release criteria from a theoretical and practical perspective, I turn now to suggest a fundamentally different approach to parole-release decisions. The approach described below aims to decrease arbitrary decision making by setting clear, individualized criteria for each person at the outset of the prison sentence. In setting specific, individualized criteria at the outset, the approach also aims to respect the agency of people in prison by providing a roadmap on which they can exercise their own judgment and realistically earn their way out of prison. Further, it takes the task of crafting substantive release criteria out of the hands of the state (which lacks the moral standing to do this task in many cases), and places this task largely in the hands of a circle of people directly impacted by the crime.

I sketch the approach below, leaving further development of it for future research. I call the approach a reparative approach because it is based on a restorative justice paradigm, but only loosely so. A restorative justice paradigm generally rejects state-centered, punitive responses to crime in favor of community-centered responses that aim to repair the harm of the crime and rebuild broken relationships. The reparative approach incorporates elements of restorative process, but it is not strictly under the banner of restorative justice because it assumes the existence of a system in which the state is still in the business of punishing people in prison for a period of time before they become eligible for release on parole. ${ }^{4}$ I have adopted this assumption not on the basis of ideal theory, but because I do not think it is reasonable to expect that the American public will take imprisonment off the table in the foreseeable future, at least not for grave crimes like murder and rape.

The reparative approach would apply in cases where a person is serving a prison sentence that includes the possibility of release. The approach would begin by convening a restorative justice circle at the outset of that sentence. 
As Johanna Luttrell describes in her article in this volume, such a circle brings together various members of the community who are impacted by a problem (or crime), who talk and listen to each other about what happened, who express the harm and discuss what can be done to repair the harm, and create an individualized and specific reparation plan that can include harsh punishment among other things. In this context, the circle would include the person who committed the crime, her friends or family, the victim and/or friends or family of the victim (the victim and people close to the victim may choose not to participate, and if so, a surrogate could participate instead), the friends or family of the victim, and representatives from the neighborhood where the perpetrator lived, where the victim lived, and where the crime happened. The circle would also include people who worked for the state and who had an influence on either the perpetrator or the victim-for example, a social worker, a teacher, a parole or probation officer, and staff at the prison where the person will be incarcerated. The circle would discuss the full depth of the harm of the crime, as well as any unjust disadvantages that the perpetrator or the victim faced prior to the crime.

After discussing the full extent of the harm, the circle would articulate two sets of goals for repairing the harm: (1) criteria that the perpetrator must meet in order to repair the harm, and (2) criteria that the community ought to work toward in order to repair the harm of the crime and any underlying conditions of injustice. For example, the community could be asked to provide the victim with individual therapy, and with an opportunity to participate in a carefully mediated victim-offender dialogue. A perpetrator could be asked to work a job in the prison to pay for those services, and to participate in programs such as substance abuse treatment, trauma-based counseling, and educational and/or vocational training. If the circle discovers that the perpetrator suffered abuse or other forms of disadvantage that affected the crime, the community could also be asked to conduct an investigation of the perpetrator's background and work toward ameliorating remaining conditions of injustice. For example, if the circle discovers that the perpetrator was sexually abused at a foster home, they could order an investigation into that foster home (or others in the area) to determine whether other children are being abused.

Critically, the criteria would be established at the outset of a person's sentence. Setting forth individualized criteria at the outset expresses that the perpetrator is a responsible agent capable of making choices for herself in the prison and acting on those choices. Once the criteria are clearly established and she knows what they are, it is up to her to fulfill them and so in some sense "earn" her way out of prison. Further it is not "the state" or its representative that would establish the criteria-as Duff has argued, the state lacks standing to hold the perpetrator accountable in cases where marked disadvantage and exclusion underlie the crime (Duff 2001). Instead, the people who are impacted by the crime create the terms of what it is to appropriately hold the perpetrator accountable. They set the standards, and 


\section{Kristen Bell}

the state acts as a mediator (of sorts) to monitor compliance with those standards. Although the state may lack moral standing to substantively craft and impose the standards, no such standing is needed to engage in the task of monitoring compliance with those standards. (The solution is imperfect because the state is still engaging in the punishment of incarceration for the years prior to the parole hearing, and in some cases the state may lack the moral standing to impose this punishment.)

Ideally, the prison sentence would come to be understood as a structured opportunity for the offender to work toward repairing the harm of the crime and for the community to work toward repairing underlying injustice that surrounded the crime. The period would be complete-and thus release on parole would be warranted-when the offender has served a minimum number of years required by the judge at sentencing and has completed the clear, individualized criteria that are set forth by those impacted by the crime. In order to reduce subjective judgments on the part of the parole board, the criteria would be specific and include a clear metric for measuring fulfillment of the criteria. For example, a criterion such as "the perpetrator should address trauma underlying the crime" would be too vague, but "the perpetrator must complete a minimum of 10 sessions of trauma-based counseling that focus on his history of being sexually abused." So long as criteria are specific and measurable, the parole-release decision would become a fairly ministerial task of measuring completion of those criteria based on established metrics.

The criteria that the restorative circle would establish would need to be reasonably achievable by the perpetrator during the minimum period of punishment. What counts as reasonably achievable will vary from person to person based on individual capacities. For example, earning a college degree and multiple vocational certifications is not reasonably within the reach of a person who has severe cognitive impairments. In addition, the criteria must be achievable with respect to the conditions of imprisonment. A representative of prison administration ought to be part of the circle to inform this discussion, and an independent body would likely be needed to ensure that the prison follows through on its commitments. (This is no small task given the current level of resources devoted to programming in prisons: according to a study of state parole boards, 44 require rehabilitation programs for release, but only two report having enough programs (Ghandnoosh 2017: 32).) After the circle decides on proposed criteria, a judge would need to determine whether the criteria are sufficiently specific, and that they are reasonably achievable from the perspective of both individual and institutional capacities. If the criteria fail on any of these fronts, the circle would be reconvened to propose an alternative plan. In addition to setting initial criteria, procedures may be developed to assess progress at various intervals during the period of incarceration and to allow for a small number of modifications to the criteria based on unanticipated developments. 
A thorough description and defense of the reparative approach is beyond the scope of this paper. It may be that sufficiently specific criteria are too difficult to agree upon in the context of grave crimes. It may also be implausible to enforce commitments that the prison provide programs that are necessary to meet the criteria. These are just some of the issues that require further research. But given the problems with existing parole-release systems and the pressing need to reform these systems, there is no better time to conduct this further research into a fundamentally different approach.

\section{Notes}

1 While I have changed the name of this person to protect his identity, all other cited facts about this case are true.

2 I thank Gideon Yaffe for calling my attention to the complexity of this question.

3 Theorists disagree on whether communication plays a central role in the moral justification of punishment. Duff, for example, maintains that the communicative aim of punishment grounds the very legitimacy of a system of crimes and punishments. On the other end of the spectrum, Victor Tadros argues that while the communicative aim of punishment is morally significant in considering how we ought to tailor punishments, it plays a cursory role (at best) in justifying the existence of a system of criminal punishment (Tadros 2011: 99-110).

4 I am drawing here on a distinction between restorative process (victim-offender mediation, sentencing circles, family-group conferences) and restorative justice (paradigm of not seeking to complement the criminal justice system but to replace it) (Robinson 2011: 353-5).

\section{References}

American Bar Association (1994). Standards for Criminal Justice: Sentencing, 3rd ed. Chicago: American Bar Association Press.

Board of Parole Hearings (2015). "Board of Parole Hearings Workload Summary.” Available at www.cdcr.ca.gov/BOPH/docs/LSTS_Workload_CY2015.pdf, accessed December 27, 2016

Braithwaite, John (2002). Restorative Justice and Responsive Regulation. Oxford: Oxford University Press.

Caldwell, Beth (2016). "Creating Meaningful Opportunities for Release: Graham, Miller, and California's Youth Offender Parole Hearings.” N.Y.U. Review of Law and Social Change 40: 245-304.

California Department of Corrections and Rehabilitation Office of Research (2016). "2015 Outcome Evaluation Report: An Examination of Offenders Released in Fiscal Year 2010-2011.” August. Available at www.cdcr.ca.gov/Adult_Research_ Branch/Research_Documents/2015_Outcome_Evaluation_Report_8-25-2016. pdf, accessed December 28, 2016

Carroll, John S. (1978). “Causal Attributions in Expert Parole Decisions.” Journal of Personality and Social Psychology 36: 1501-11.

Carroll, John S., Weiner, Richard, Coates, Dan, Albrio, James (1982). "Evaluation, Diagnosis, and Prediction in Parole Decision Making." Law and Society Review 17: 199-228. 


\section{Kristen Bell}

Carson, E. Ann (2015). "Prisoners in 2014." September. Department of Justice, Bureau of Justice Statistics. Available at www.bjs.gov/content/pub/pdf/p14.pdf, accessed December 27, 2016

Conley, John A and Zimmerman, Sherwood (1982). "Decison-Making by a Part-Time Parole Board: An Observational and Empirical Study." Criminal Justice and Behavior 9 (December): 396-431.

Duff, R.A. (2001). Punishment, Communication, and Community. Oxford: Oxford University Press.

Duff, R.A. (2011). "Restorative Punishment and Punitive Restoration.” In Why Punish? How Much? ed. M. Tonry. Oxford: Oxford University Press, 367-82.

Garber, Robert M and Maslach, Christina (1977). "The Parole Hearing: Decision or Justification." Law and Human Behavior 1: 261-81.

Ghandnoosh, Nazgol (2017). "Delaying a Second Chance: The Declining Prospects for Parole on Life Sentences." The Sentencing Project. Available at www.sentencingproject.org/wp-content/uploads/2017/01/Delaying-a-Second-Chance.pdf, accessed March 12, 2017

Hampton, Jean (1988). “The Retributive Idea.” In Forgiveness and Mercy, ed. J.M. Hampton. New York: Cambridge University Press, 111-61.

Holland, Terrill, Holt, Norman, and Brewer, David (1978). "Social Roles and Information Utilization in Parole Decision-Making.” Social Psychology 106: 111-20.

Justice Policy Institute (2016). "Defining Violence: Reducing Incarceration by Rethinking America's Approach to Violence." August. Available at www. justicepolicy.org/uploads/justicepolicy/documents/jpi_definingviolence_final_ report_9.7.2016.pdf, accessed December 28, 2016

Kobrin, Sandra (2005). “Dying on Our Dime.” Los Angeles Times, June 26.

Kuznia, Rob (2016). "An Unprecedented Experiment in Mass Forgiveness.” The Washington Post, February 8.

Larson, Jeff, Mattu, Surya, Kirchner, Lauren, and Angwin, Julia (2016). "How We Analyzed the COMPAS Recidivism Algorithm.” May 23. Available at www.propublica.org/article/how-we-analyzed-the-compas-recidivism-algorithm.

Mehta, S. (2016). "False Hope: How Parole Systems Fail Youth Serving Extreme Sentences.” American Civil Liberties Union. November. Available at www.aclu. org/feature/false-hope-how-parole-systems-fail-youth-serving-extreme-sentences.

Mullane, N. (2012). Life After Murder: Five Men in Search of Redemption. New York: Public Affairs.

Nellis, A. (2013). Life Goes On: The Historic Rise in Life Sentences in America. Available at http://sentencingproject.org/wp-content/uploads/2015/12/Life-GoesOn.pdf, accessed December 27, 2016.

Rhine, Edward E. (2012). "The Present Status and Future Prospects of Parole Boards and Parole Supervision." In The Oxford Handbook of Sentencing and Corrections, ed. K.R. Joan Petersilia. Oxford: Oxford University Press, 627-56.

Rhine, Edward E., Petersilia, Joan, and Reitz, Kevin (2017). "The Future of Parole Release: A Ten Point Plan.” In Crime and Justice: Reinventing American Criminal Justice, ed. M. Tonry. Chicago: University of Chicago Press.

Robert Weisberg, Mukamal, Debbie, and Segall, Jordan (2011). "Life in Limbo: An Examination of Parole Release for Prisoners Serving Life Sentences with the Possibility of Parole in California." September. Available at http://law.stanford.edu/ wp-content/uploads/sites/default/files/child-page/164096/doc/slspublic/SCJC_ report_Parole_Release_for_Lifers.pdf 
Robinson, Paul (2011). “The Virtues of Restorative Process, The Vices of 'Restorative Justice.' " In Why Punish? How Much, ed. M. Tonry. Oxford: Oxford University Press, 353-67.

Ruhland, Ebony, Rhine, Edward, Robey, Jason, and Mitchell, Kelly Lyn (2016). "The Continuing Leverage of Releasing Authorities: Findings from a National Survey." Available at https://robinainstitute.umn.edu/publications/continuing-leveragereleasing-authorities-findings-national-survey, accessed December 27, 2016

Schwartzapfel, Beth (2015). "How Parole Boards Keep Prisoners in the Dark and Behind Bars." The Washington Post, July 11.

Scott, Joseph (1974). "The Use of Discretion in Determining the Severity of Punishment for Incarcerated Offenders." Journal of Criminal Law and Criminology 656: 214-24.

Tadros, Victor (2011). The Ends of Harm: The Moral Foundations of Criminal Law. Oxford: Oxford University Press.

Vera Institute of Justice (1978). Final Report on Parole Decision-Making Project Sumbitted to NYS Department of Correctional Services. Vera Institute of Justice: New York.

Winerip, Michael, Schwirtz, Michael, and Gebeloff, Robert (2016). "For Blacks Facing Parole in New York State, Signs of a Broken System.” The New York Times, December 4.

Young, Kathryne M., Mukamal, Debbie, and Favre-Bulle, Thomas (2016). "Predicting Parole Grants: An Analysis of Suitability Hearings for California's Lifer Inmates." Federal Sentencing Reporter 28: 268-77. 